\title{
KAJIAN TEKNIS PENGGUNAAN TERRAMESH SEBAGAI DINDING PENAHAN TANAH PADA PROYEK JALAN TOL JAKARTA-KUNCIRAN-CENGKARENG
}

\author{
Andrew Horas ${ }^{1}$, Aniek Prihatiningsih ${ }^{2}$, dan Josephine Aristiti Setyarini ${ }^{3}$ \\ IProgram Studi Sarjana Teknik Sipil, Universitas Tarumanagara, Jl. Letjen S. Parman No.1 Jakarta \\ Email: andrewhoras@gmail.com \\ 2Program Studi Sarjana Teknik Sipil, Universitas Tarumanagara, Jl. Letjen S. Parman No.1 Jakarta \\ Email: aniekprihatiningsih@gmail.com \\ 3Program Studi Sarjana Teknik Sipil, Universitas Tarumanagara, Jl. Letjen S. Parman No.1 Jakarta \\ Email: josephine.setyarini@gmail.com
}

\begin{abstract}
ABSTRAK
Lereng yang curam adalah masalah dalam bidang geoteknik yang sering dijumpai. Lereng tersebut dapat terbentuk secala alami maupun buatan. Salah satu lereng buatan yang terbentuk dari penimbunan tanah seperti jalan tol di Jakarta. Lahan yang terbatas menjadi alasan utama terbentuknya lereng yang hampir tegak $90^{\circ}$ sehingga dibutuhkan perkuatan. Salah satu perkuatan yaitu menggunakan Terramesh dan geogrid. Keterbatasan data tanah menjadi salah satu permasalahan dalam kasus ini. Data laboratorium tidak tersedia sehingga digunakan berbagai korelasi berdasarkan nilai N-SPT. Analisis mendalam dilakukan dengan penetuan nilai koefisien pengali kuat geser tidak terdrainase $(\mathrm{Su})$. Hasil korelasi tersebut akan dimasukkan sebagai parameter dalam program yang berbasis elemen hingga. Nilai angka keamanan dari stabilitas lereng akan menjadi hasil keluaran program. Nilai tersebut menunjukkan bahwa penggunaan Terramesh dan geogrid di jalan tol di Jakarta cukup efektif digunakan sebagai perkuatan lereng akibat timbunan.
\end{abstract}

Kata kunci: stabilitas lereng, angka keamanan, Terramesh, geogrid, $N$-SPT.

\section{PENDAHULUAN}

\section{Latar belakang}

Indonesia adalah salah satu negara disebut sebagai negara berkembang. Hal ini dapat terlihat dengan perkembangan pesat yang terjadi dalam berbagai sektor, misal: sektor perekonomian, sektor industri, infrastruktur, dll. Perkembangan masyarakat Indonesia yang terus meningkat mendorong pemerintah untuk mengembangkan berbagai sektor dalam roda pemerintahan, salah satunya adalah sektor infrastruktur.

Namun, tingginya kebutuhan masyarakat mendorong adanya pembangunan berkelanjutan di bidang infrastruktur, khususnya jalan bebas hambatan (jalan tol). Proyek pembangunan jalan tol di Jakarta yang berada di bawah pengawasan Jasamarga adalah salah satu proyek jalan bebas hambatan (jalan tol) yang masih berjalan. Ruas jalan yang membentang pada topografi yang memiliki lereng yang curam (kemiringan lebih dari 25\%) memiliki tingkat kerawanan yang sangat tinggi dalam bahaya longsor. Kuat geser tanah yang menurun akibat adanya rembesan dalam tanah dan tegangan dalam tanah yang meningkat akibat aktivitas lalu lintas menjadi penyebab umum terjadinya longsor.Solusi untuk mencegah terjadinya bahaya longsor yang terjadi pada badan jalan adalah dengan mengadakan investigasi dan perhitungan yang cermat terhadap kestabilan lereng. Analisis stabilitas lereng berfungsi untuk menghitung dan membandingkan tegangan geser yang terbentuk sepanjang bidang gelincir terhadap tegangan geser tanah yang ditinjau. Selain itu, terdapat juga nilai safety factor yang didefinisikan sebagai nilai perbandingan kuat geser yang dimiliki tanah dengan tegangan geser tanah tersebut.

\section{Batasan masalah}

Dalam penelitian ini, batasan-batasan yang digunakan sebagai berikut:

1. Data penyelidikan tanah yang diperoleh borelog di titik terdekat dengan dinding penahan tanah.

2. Lokasi yang ditinjau berada di Benda Junction, Benda.

3. Analisis stabilitas lereng menggunakan program.

4. Beban rencana yang digunakan adalah sebesar $15 \mathrm{kN} / \mathrm{m}^{2}$.

5. Geogrid digunakan dari MacGrid WG8.

6. Material tanah menggunakan model Mohr-Coulomb.

7. Pemodelan Terramesh dengan cluster menggunakan model Mohr-Coulomb. 


\section{Rumusan masalah}

Rumusan masalah yang akan dibahas pada penelitian ini:

1. Analisis stabilitas lereng badan jalan tol di Jakarta.

2. Angka keamanan lereng jalan tol di Jakarta akibat beban-beban yang bekerja.

3. Angka keamanan lereng jalan tol di Jakarta setelah diperkuat dengan pemasangan Terramesh.

4. Konfigurasi pemasangan Terramesh yang dipasang di lereng badan jalan.

5. Menentukan keefektifan pemasangan Terramesh sebagai dinding penahan tanah.

\section{Tujuan penelitian}

Beberapa tujuan dari penelitian ini adalah untuk mengkaji secara teknik apakah lereng curam yang terdapat di badan jalan tol di Jakarta termasuk dalam kategori yang aman atau tidak, apabila tidak ada perkuatan dan penentuan soil parameter. Apabila diperlukannya perkuatan, solusi pemasangan Terramesh sebagai dinding penahan tanah untuk lereng tersebut adalah pilihan yang efektif dari segi struktural.

\section{Lereng dan Longsoran}

Lereng adalah permukaan bumi yang membentuk sudut kemiringan tertentu dengan bidang horizontal. Lereng dapat terbentuk secara alami maupun buatan manusia. Lereng yang terbetuk secara alami adalah bukit dan tebing sungai, sedangkan lereng buatan adalah galian dan timbunan untuk membuat bendungan, tanggul, kanal, dll. (Arief, 2007). Pada dasarnya tanah longsor terjadi apabila gaya pendorong pada lereng lebih besar daripada gaya penahan. Gaya penahan umumnya dipengaruhi oleh kekuatan batuan dan kepadatan tanah, sedangkan gaya pendorong dipengaruhi oleh besarnya sudut kemiringan lereng, air, beban, dan berat jenis tanah.

\section{Faktor Keamanan (Safety Factor)}

Analisis stabilitas lereng didasarkan pada konsep umum keseimbangan batas (General Limit Equilibrium) guna menghitung faktor keamanan. Secara teoritis, faktor keamanan dapat didefinisikan sebagai berikut:

$$
F_{s}=\frac{\tau_{f}}{\tau_{d}}
$$

Keterangan:

$F_{S}=$ Faktor keamanan terhadap kekuatan tanah.

$\tau_{f}=$ Kekuatan geser rata-rata dari tanah yang ditinjau $\left(\mathrm{kN} / \mathrm{m}^{2}\right)$.

$\tau_{d}=$ Tegangan geser rata-rata yang bekerja sepanjang bidang gelincir $\left(\mathrm{kN} / \mathrm{m}^{2}\right)$.

\section{Terramesh}

Terramesh adalah anyaman kawat yang berbentuk kotak terbuat dari kawat baja berlapis seng yang diisi batuan dan kerikil untuk mencegah kelongsoran pada tanah yang dipasang pada lereng, tepi sungai dan tebing. Dibandingkan dengan beton yang umumnya digunakan sebagai dinding penahan tanah, Terramesh memiliki keunggulan, antara lain:

1. Tumpukan batu-batu di dalam Terramesh memungkinkan air untuk mengalir disela-sela batuan sehingga tekangan tanah akan berkurang dan mengurangi resiko longsor.

2. Bentuk yang sederhana sehingga dapat dilaksanakan tanpa menggunakan mesin berteknologi tinggi.

3. Menjadi salah satu alternatif untuk daerah-daerah yang terpencil, dimana akses jalan yang masih sangat minim.

\section{Geogrid}

Geogrid adalah salah satu contoh dari jenis geosintektik yang berbentuk jaring terbuka. Geogrid merupakan bahan sintetis dari polyethylene, polyester, polypropylene, polyamide, dan aramide, bertegangan tinggi yang diseleksi berdasarkan tingkat kerapatannya, lalu diproses dalam pabrik.

Fungsi utama geogrid adalah sebagai perkuatan yang mengacu pada mekanisme dimana sifat tanah dapat ditingkatkan secara mekanis. Geogrid dibentuk oleh suatu jaring teratur dengan elemen tarik dan mempunyai bukaan berukuran tertentu sehingga saling mengunci dengan bahan pengisi di sekelilingnya. Berdasarkan bentuk bukaannya, maka geogrid dibagi menjadi tiga, yaitu:

\section{Uniaxial Geogrid}


Uniaxial grid berbentuk lembaran masif dengan celah yang memanjang dengan bahan dasar HDPE (High Density Polyethelene). Tipe ini banyak digunakan untuk perkuatan tanah pada DPT (Dinding Penahan Tanah) dan untuk memperbaiki lereng yang longsor degan menggunakan tanah setempat.

\section{Biaxial Geogrid}

Biaxial geogrid terbuat dari bahan dasar polypropylene (PP) dan banyak digunakan untuk meningkatkan tanah dasar lunah $(\mathrm{CBR}<1 \%)$. Biaxial geogrid adalah lembaran bujursangkar dimana dengan struktur lubang bujursangkar ini partikel timbunan akan saling terkunci dan kuat geser tanah akan naik.

\section{Triax Geogrid}

Fungsi utama geogrid ini sama dengan Biaxial Geogrid hanya saja performance geogrid ini lebih baik. Hal ini disebabkan oleh bentuk bukaannya segitiga, sehingga lebih kaku dan penyebaran beban menjadi lebih merata.

\section{METODOLOGI PENELITIAN}

\section{Metode pengumpulan data}

Kajian teknis kali ini berada di lokasi proyek jalan tol di Jakarta. Benda Junction, Benda. Data yang dikumpulkan adalah berdasarkan hasil peninjauan di lokasi proyek dengan pengamatan, pencatatan, dan wawancara sehingga data yang diperoleh adalah data yang sesuai terjadi di lokasi proyek. Data yang dikumpulkan adalah data hasil tes SPT (Standart Penetration Test), lay out lokasi proyek, dan kondisi awal lereng.

\section{Metode analisis data}

Studi literatur adalah hal pertama yang dilakukan sebelum analisis data. Studi ini berguna untuk mengetahui dasardasar teori dinding penahan tanah, angka keamanan, dll. Setelah studi literatur dilakukan pengumpulan data dari lokasi proyek sebagai dasar perhitungan, dalam hal ini adalah data borelog dimana angka N-SPT akan diolah dengan berbagai korelasi untuk menentukan nilai-nilai parameter yang dibutuhkan untuk analisis. Pemodelan profil tanah akan dimasukkan ke dalam program, dalam hal ini program analisis berbasis elemen hingga. Ada 2 kondisi untuk dianalisis, pertama dengan menganalisis kestabilan lereng pada kondisi alami dan selanjutnya menganalisis stabilitas lereng dengan perkuatan. Perkuatan yang diterapkan dalam studi ini adalah dengan menggunakan geogrid, terramesh, dan kombinasi keduanya. Ketika mendapatkan nilai angka keamanan dari masing-masing kondisi maka akan dilanjutkan dengan tahap pembahasan. Tahap ini akan membahas nilai-nilai angka keamanan dari kedua kondisi sehingga dapat ditarik beberapa kesimpulan sesuai dengan hasil perhitungan.

\section{ANALISIS DAN PEMBAHASAN}

\section{Kesimpulan parameter tanah}

Nilai semua parameter tanah didapatkan dari korelasi terhadap nilai N-SPT. Berikut merupakan kesimpulan parameter yang didapatkan dari 4 buah borelog terdekat untuk pemodelan dalam program berbasis elemen hingga yang dapat dilihat pada table 1 sebagai berikut:

Tabel 1 Rangkuman parameter yang digunakan

\begin{tabular}{|c|c|c|c|c|c|c|c|c|c|c|c|c|c|}
\hline Layer & $\begin{array}{l}\text { Soil } \\
\text { Type }\end{array}$ & $\begin{array}{c}\text { Soil } \\
\text { Consistency }\end{array}$ & \multicolumn{3}{|c|}{ Depth (m) } & $\mathrm{N}_{\mathrm{SPT}}$ & $\begin{array}{c}\phi \\
\left({ }^{\circ}\right)\end{array}$ & $\begin{array}{c}\mathrm{c}^{\prime} \\
\left(\mathrm{kN} / \mathrm{m}^{2}\right)\end{array}$ & $\underset{\left(\mathrm{kN} / \mathrm{m}^{2}\right)}{\mathrm{Eu}}$ & $\begin{array}{c}E^{\prime} \\
\left(k N / m^{2}\right)\end{array}$ & $\mathrm{v}$ & $\begin{array}{c}\gamma \mathrm{sat} \\
\left(\mathrm{kN} / \mathrm{m}^{3}\right)\end{array}$ & $\underset{\left(\mathrm{kN} / \mathrm{m}^{2}\right)}{\mathrm{Su}}$ \\
\hline 1 & Clay & Stiff & 0 & - & 4 & 11 & 25 & 10 & 18000 & 12000 & 0.3 & 14 & 60 \\
\hline 2 & Clay & Soft & 4 & - & 6 & 3 & 23 & 11 & 19000 & 11000 & 0.3 & 14 & 45 \\
\hline 3 & Clay & Stiff & 6 & - & 10 & 10 & 28 & 15 & 22000 & 15000 & 0.3 & 16 & 65 \\
\hline 4 & Silt & Very Stiff & 10 & - & 14 & 23 & 32 & 19 & 35000 & 20000 & 0.3 & 17 & 100 \\
\hline 5 & Sand & Dense & 14 & - & 20 & 32 & 35 & 0 & 30000 & 18000 & 0.3 & 18 & 105 \\
\hline 6 & Clay & Very Stiff & 20 & - & 28 & 18 & 29 & 22 & 40000 & 25000 & 0.3 & 16 & 120 \\
\hline 7 & Clay & Very Stiff & 28 & - & 32 & 16 & 29 & 22 & 35000 & 20000 & 0.3 & 16 & 110 \\
\hline 8 & Clay & Very Stiff & 32 & - & 36 & 16 & 29 & 23 & 35000 & 20000 & 0.3 & 17 & 125 \\
\hline 9 & Clay & $\begin{array}{l}\text { Very Stiff } \\
\text { Medium }\end{array}$ & 36 & - & 42 & 18 & 29 & 26 & 42000 & 22000 & 0.3 & 17 & 125 \\
\hline 10 & Sand & Dense & 42 & - & 46 & 25 & 32 & 0 & 40000 & 25000 & 0.3 & 19 & 145 \\
\hline 11 & Clay & Very Stiff & 46 & - & 50 & 24 & 32 & 32 & 50000 & 28000 & 0.3 & 18 & 150 \\
\hline
\end{tabular}




\section{Material yang dipakai dalam pemodelan}

Dalam pemodelan, digunakan material Terramesh dan geogrid sebagai perkuatan lereng. Parameter perkuatan dengan Terramesh:

Tabel 2 Parameter input Terramesh

\begin{tabular}{lcl}
\hline \multicolumn{3}{c}{ Parameter Terramesh } \\
\hline Material mode & $:$ & Mohr-Coulomb \\
Material type & $:$ & Non-porous \\
$\gamma_{\mathrm{sat}}$ & $:$ & $20 \mathrm{kN} / \mathrm{m}^{3}$ \\
$\mathrm{E}_{\mathrm{ref}}$ & $:$ & $100000 \mathrm{kN} / \mathrm{m}^{2}$ \\
$v$ & $:$ & 0.3 \\
$\mathrm{c}_{\mathrm{ref}}$ & $:$ & $200 \mathrm{kN} / \mathrm{m}^{2}$ \\
$\phi$ & $:$ & 45 \\
$\psi$ & $:$ & 0 \\
\hline
\end{tabular}

Geogrid yang digunakan merupakan MacGrid WG8 (Sumber: Brosur Maccaferri) dengan data material yang digunakan sebagai berikut :

Tabel 3 Parameter input Geogrid

\begin{tabular}{lcc}
\hline \multicolumn{3}{c}{ Parameter Geogrid } \\
\hline Material type & $:$ & Elastoplastic \\
A & $:$ & $8000 \mathrm{kN} / \mathrm{m}$ \\
$\mathrm{Np}$ & $:$ & $47 \mathrm{kN} / \mathrm{m}$ \\
\hline
\end{tabular}

Hasil nilai angka keamanan tanpa perkuatan dengan bantuan program

Gambar 4 Nilai angka keamanan tanpa perkuatan

\begin{tabular}{ccccc}
\hline Faktor Pengali, Cu & SF & SF Beban & SF Gempa & SF Beban + Gempa \\
\hline $5 \mathrm{~N}$ & 1.06 & 0.93 & 0.52 & 0.54 \\
$6 \mathrm{~N}$ & 1.08 & 0.95 & 0.6 & 0.97 \\
$7 \mathrm{~N}$ & 0.94 & 1.16 & 0.43 & 0.6 \\
$8 \mathrm{~N}$ & 1.07 & 1.27 & 0.59 & 0.85 \\
\hline
\end{tabular}

Dari Tabel diatas dapat dilihat bahwa nilai faktor keamanan dengan timbunan terkonsolidasi di bawah 1.5, sehingga dapat disimpulkan bahwa lereng tersebut tidak aman dan dibutuhkan adanya perkuatan.

\section{Tahapan konstruksi}

Tabel 3 Tahapan kosntruksi

\begin{tabular}{clc}
\hline No & \multicolumn{1}{c}{ Tahap Konstruksi } & $\begin{array}{c}\text { Durasi } \\
\text { (hari) }\end{array}$ \\
\hline 1 & Pemasngan Terramesh & 3 \\
2 & Timbunan tanah setinggi 1 meter (Ketinggian 1 meter) & 5 \\
3 & Konsolidasi timbunan & 10 \\
4 & Pemasangan Terramesh dan Geogrid & 5 \\
5 & Timbunan tanah setinggi 1 meter (Ketinggian 2 meter) & 5 \\
6 & Konsolidasi timbunan & 10
\end{tabular}


7 Pemasangan Terramesh dan Geogrid 5

8 Timbunan tanah setinggi 1 meter (Ketinggian 3 meter) 5

9 Konsolidasi timbunan 10

10 Timbunan tanah setinggi 1 meter (Ketinggian 4 meter) 5

11 Konsolidasi timbunan $\quad 10$

12 Timbunan tanah setinggi 1 meter (Ketinggian 5 meter) 5

13 Konsolidasi timbunan 10

14 Timbunan tanah setinggi 1 meter (Ketinggian 6 meter) 5

15 Konsolidasi timbunan 10

16 Perhitungan nilai angka keamanan lereng timbunan 6 meter -

17 Beban lalu lintas diaktifkan

18 Perhitungan nilai angka keamanan akibat beban lalu lintas

19 Beban gempa diaktifkan

20 Perhitungan nilai angka keamanan akibat beban gempa

21 Beban gempa dan lalu lintas diaktifkan

22 Perhitungan nilai angka keamanan akibat beban gempa dan lalu lintas

\section{Kondisi short term dengan perkuatan geogrid}

Dalam kasus ini geogrid akan dipasang setiap kenaikan 1 meter hingga 6 meter. Nilai angka keamanan dalam kondisi ditinjau dalam beberapa kasus. Kasus pertama, geogrid akan dipasang 1 buah untuk timbunan 6 meter. Kasus kedua, geogrid akan dipasang sebanyak 2 buah untuk timbunan setinggi 6 meter hingga pada akhirnya geogrid akan terpasang sebanyak 5 buah dengan tinggi timbunan 6 meter.

Tabel 4 Nilai angka keamanan perkuatan dengan 1 Geogrid

\begin{tabular}{ccccc}
\hline Faktor Pengali,Cu & SF & SF beban & SF Gempa & SF Beban + Gempa \\
\hline $5 \mathrm{~N}$ & 1.87 & 1.62 & 1.40 & 1.22 \\
$6 \mathrm{~N}$ & 2.16 & 2.09 & 1.41 & 1.28 \\
$7 \mathrm{~N}$ & 1.94 & 1.54 & 1.37 & 1.16 \\
$8 \mathrm{~N}$ & 1.88 & 1.55 & 1.37 & 1.19 \\
\hline
\end{tabular}

Tabel 5 Nilai angka keamanan perkuatan dengan 2 Geogrid

\begin{tabular}{ccccc}
\hline Faktor Pengali,Cu & SF & SF beban & SF Gempa & SF Beban + Gempa \\
\hline $5 \mathrm{~N}$ & 2.23 & 1.96 & 1.40 & 1.26 \\
$6 \mathrm{~N}$ & 2.38 & 2.07 & 1.41 & 1.24 \\
$7 \mathrm{~N}$ & 2.34 & 1.85 & 1.40 & 1.21 \\
$8 \mathrm{~N}$ & 2.38 & 1.81 & 1.41 & 1.25 \\
\hline
\end{tabular}

Tabel 6 Nilai angka keamanan perkuatan dengan 3 Geogrid

\begin{tabular}{ccccc}
\hline Faktor Pengali,Cu & SF & SF beban & SF Gempa & SF Beban + Gempa \\
\hline $5 \mathrm{~N}$ & 2.25 & 1.96 & 1.42 & 1.26 \\
$6 \mathrm{~N}$ & 2.34 & 2.03 & 1.44 & 1.28 \\
$7 \mathrm{~N}$ & 2.68 & 1.94 & 1.42 & 1.26 \\
$8 \mathrm{~N}$ & 2.50 & 1.94 & 1.43 & 1.26 \\
\hline
\end{tabular}


Tabel 7 Nilai angka keamanan perkuatan dengan 4 Geogrid

\begin{tabular}{ccccc}
\hline Faktor Pengali,Cu & SF & SF beban & SF Gempa & SF Beban + Gempa \\
\hline $5 \mathrm{~N}$ & 2.25 & 1.98 & 1.45 & 1.28 \\
$6 \mathrm{~N}$ & 2.34 & 2.07 & 1.45 & 1.27 \\
$7 \mathrm{~N}$ & 2.52 & 1.97 & 1.60 & 1.49 \\
$8 \mathrm{~N}$ & 2.45 & 1.97 & 1.57 & 1.27 \\
\hline
\end{tabular}

Tabel 8 Nilai angka keamanan perkuatan dengan 5 Geogrid

\begin{tabular}{ccccc}
\hline Faktor Pengali,Cu & SF & SF beban & SF Gempa & SF Beban + Gempa \\
\hline $5 \mathrm{~N}$ & 2.25 & 1.98 & 1.45 & 1.28 \\
$6 \mathrm{~N}$ & 2.33 & 2.01 & 1.46 & 1.28 \\
$7 \mathrm{~N}$ & 2.49 & 2.01 & 1.63 & 1.41 \\
$8 \mathrm{~N}$ & 2.41 & 2.01 & 1.47 & 1.28 \\
\hline
\end{tabular}

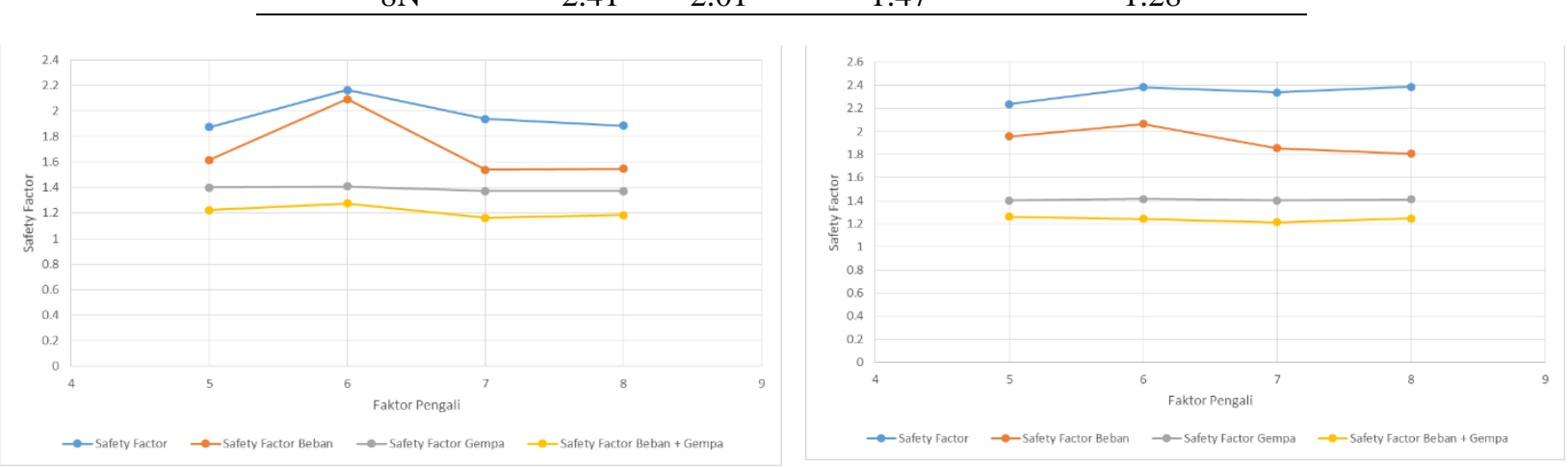

Gambar 1 Angka keamanan perkuatan dengan 1 Geogrid (kiri) dan perkuatan dengan 2 Geogrid (kanan)
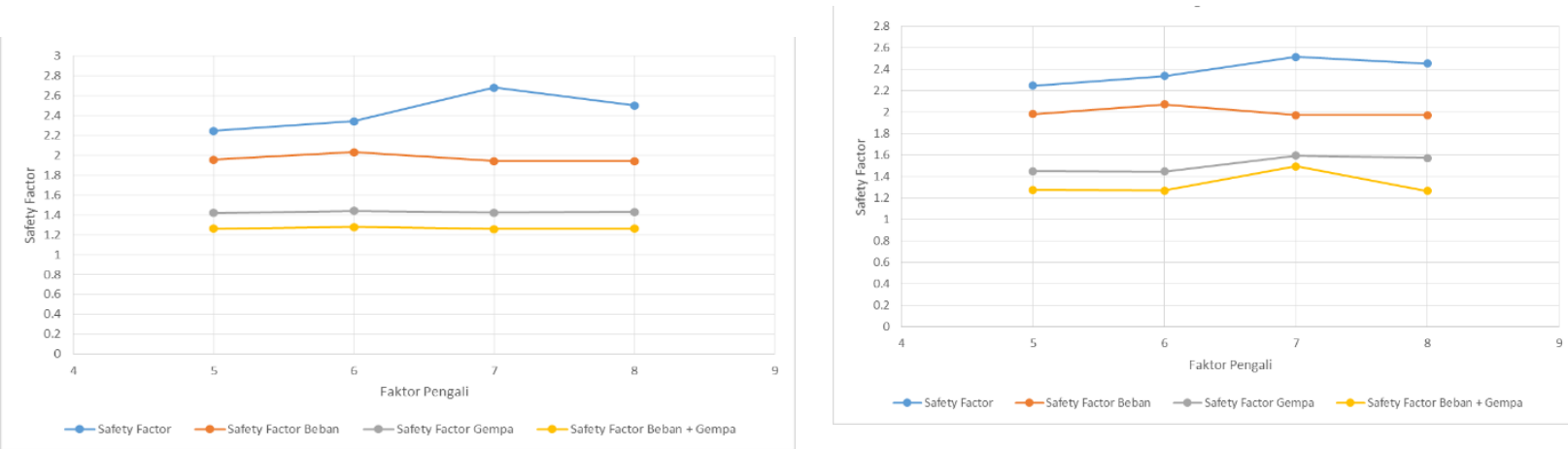

Gambar 2 Angka keamanan perkuatan dengan 3 Geogrid (kiri) dan perkuatan dengan 4 Geogrid (kanan)

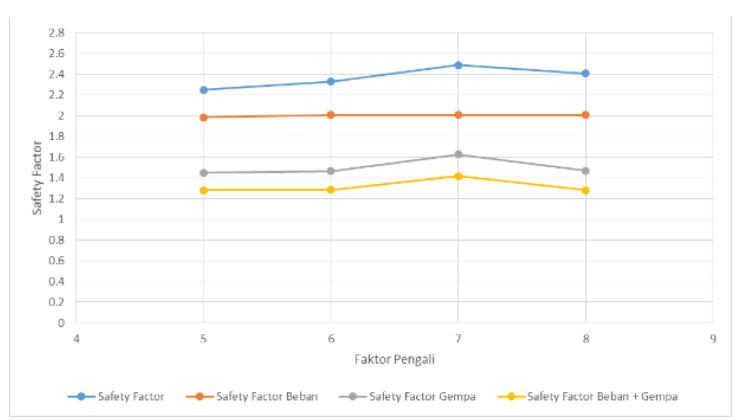

Gambar 3 Angka keamanan perkuatan dengan 5 Geogrid 


\section{Kondisi short term dengan perkuatan terramesh}

Dalam kasus ini terramesh dipasang setinggi 3 meter dengan perubahan pada nilai kuat geser tak terdrainase (Su). Nilai angka keamanan didapatkan sebagai berikut:

Tabel 9 Nilai angka keamanan perkuatan dengan terramesh

\begin{tabular}{ccccc}
\hline Faktor Pengali,Cu & SF & SF beban & SF Gempa & SF Beban + Gempa \\
\hline $5 \mathrm{~N}$ & 2.25 & 1.76 & 1.54 & 1.35 \\
$6 \mathrm{~N}$ & 2.46 & 1.94 & 1.72 & 1.49 \\
$7 \mathrm{~N}$ & 2.69 & 2.17 & 1.88 & 1.62 \\
$8 \mathrm{~N}$ & 3.13 & 2.22 & 2.05 & 1.70 \\
\hline
\end{tabular}

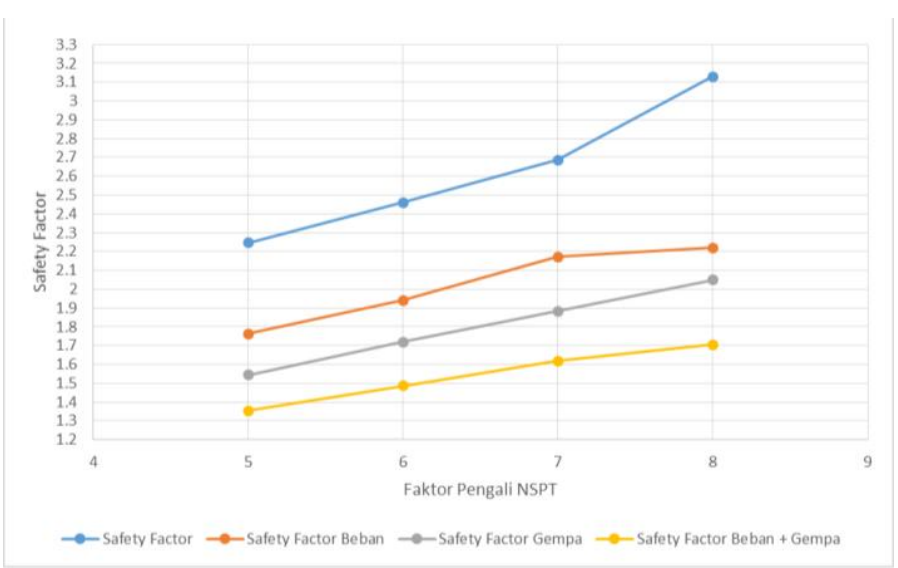

Gambar 4 Angka keamanan perkuatan dengan Terramesh

\section{Kondisi short term dengan perkuatan geogrid dan terramesh}

Dalam kasus ini terramesh dan geogrid akan dipasang setiap kenaikan 1 meter hingga 6 meter. Terramesh terpasang sehingga yang berganti adalah jumlah geogrid yang terpasang. Nilai angka keamanan dalam kondisi ditinjau dalam beberapa kasus. Kasus pertama, geogrid akan dipasang 1 buah untuk timbunan 6 meter. Kasus kedua, geogrid akan dipasang sebanyak 2 buah untuk timbunan setinggi 6 meter hingga pada akhirnya geogrid akan terpasang sebanyak 5 buah dengan tinggi timbunan 6 meter.

Tabel 10 Nilai angka keamanan perkuatan dengan 1 Geogrid dan Terramesh

\begin{tabular}{ccccc}
\hline Faktor Pengali,Cu & SF & SF beban & SF Gempa & SF Beban + Gempa \\
\hline $5 \mathrm{~N}$ & 2.39 & 1.86 & 1.61 & 1.49 \\
$6 \mathrm{~N}$ & 2.39 & 2.02 & 1.74 & 1.59 \\
$7 \mathrm{~N}$ & 3.15 & 1.85 & 1.76 & 1.47 \\
$8 \mathrm{~N}$ & 3.71 & 2.85 & 2.07 & 1.83 \\
\hline
\end{tabular}

Tabel 11 Nilai angka keamanan perkuatan dengan 2 Geogrid dan Terramesh

\begin{tabular}{ccccc}
\hline Faktor Pengali,Cu & SF & SF beban & SF Gempa & SF Beban + Gempa \\
\hline $5 \mathrm{~N}$ & 2.32 & 2.05 & 1.60 & 1.47 \\
$6 \mathrm{~N}$ & 2.46 & 2.16 & 1.74 & 1.58 \\
$7 \mathrm{~N}$ & 3.03 & 2.41 & 1.92 & 1.70 \\
$8 \mathrm{~N}$ & 3.74 & 2.83 & 2.07 & 1.82 \\
\hline
\end{tabular}


Tabel 12 Nilai angka keamanan perkuatan dengan 3 Geogrid dan Terramesh

\begin{tabular}{ccccc}
\hline Faktor Pengali,Cu & SF & SF beban & SF Gempa & SF Beban + Gempa \\
\hline $5 \mathrm{~N}$ & 2.32 & 2.05 & 1.61 & 1.48 \\
$6 \mathrm{~N}$ & 2.53 & 2.19 & 1.93 & 1.76 \\
$7 \mathrm{~N}$ & 3.06 & 2.64 & 1.93 & 1.71 \\
$8 \mathrm{~N}$ & 3.80 & 2.66 & 2.06 & 1.81 \\
\hline
\end{tabular}

Tabel 13 Nilai angka keamanan perkuatan dengan 4 Geogrid dan Terramesh

\begin{tabular}{ccccc}
\hline Faktor Pengali,Cu & SF & SF beban & SF Gempa & SF Beban + Gempa \\
\hline $5 \mathrm{~N}$ & 2.33 & 2.05 & 1.61 & 1.48 \\
$6 \mathrm{~N}$ & 2.50 & 2.15 & 1.73 & 1.58 \\
$7 \mathrm{~N}$ & 3.08 & 2.65 & 1.94 & 1.73 \\
$8 \mathrm{~N}$ & 3.65 & 2.83 & 2.06 & 1.82 \\
\hline
\end{tabular}

Tabel 14 Nilai angka keamanan perkuatan dengan 5 Geogrid dan Terramesh

\begin{tabular}{ccccc}
\hline Faktor Pengali,Cu & SF & SF beban & SF Gempa & SF Beban + Gempa \\
\hline $5 \mathrm{~N}$ & 2.34 & 2.05 & 1.61 & 1.48 \\
$6 \mathrm{~N}$ & 2.48 & 2.15 & 1.73 & 1.58 \\
$7 \mathrm{~N}$ & 3.09 & 2.66 & 1.95 & 1.74 \\
$8 \mathrm{~N}$ & 3.71 & 2.85 & 2.07 & 1.83 \\
\hline
\end{tabular}
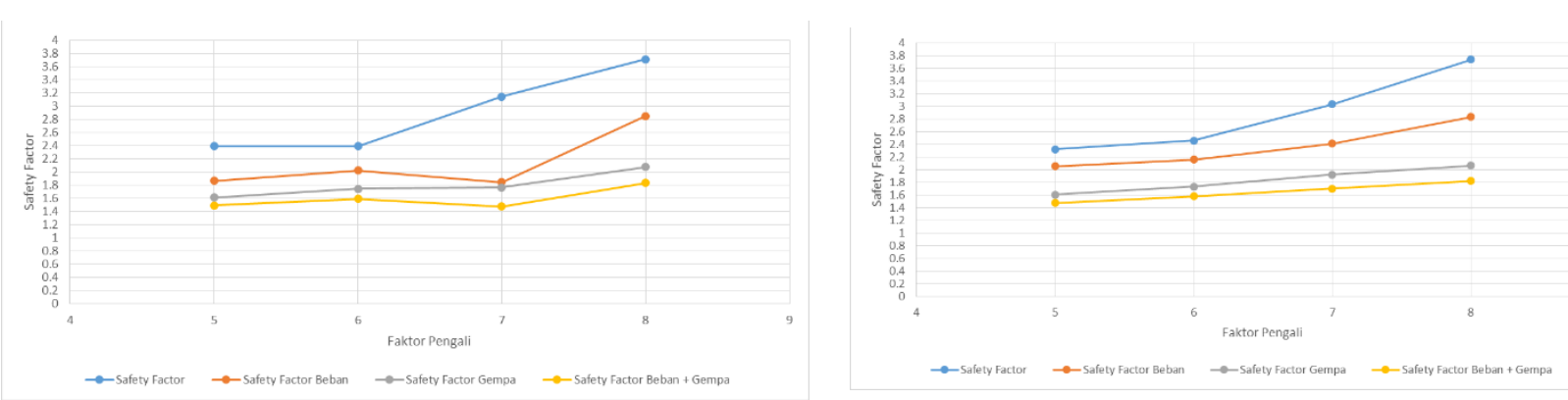

Gambar 5 Angka keamanan perkuatan dengan 1 Geogrid dan Terramesh (kiri) dan angka keamanan perkuatan dengan 2 Geogrid dan Terramesh (kanan).
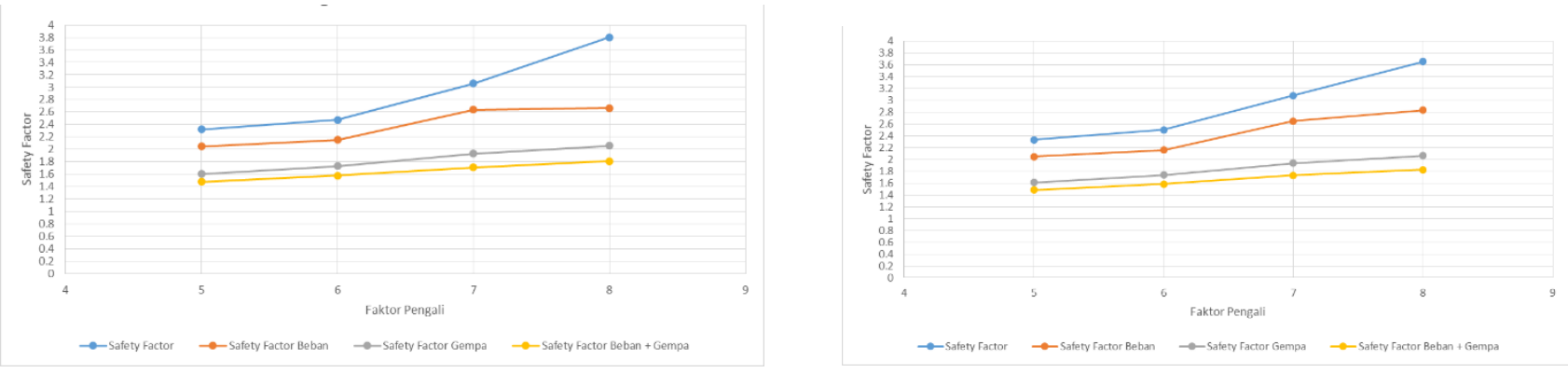

Gambar 5 Angka keamanan perkuatan dengan 3 Geogrid dan Terramesh (kiri) dan angka keamanan perkuatan dengan 4 Geogrid dan Terramesh (kanan). 


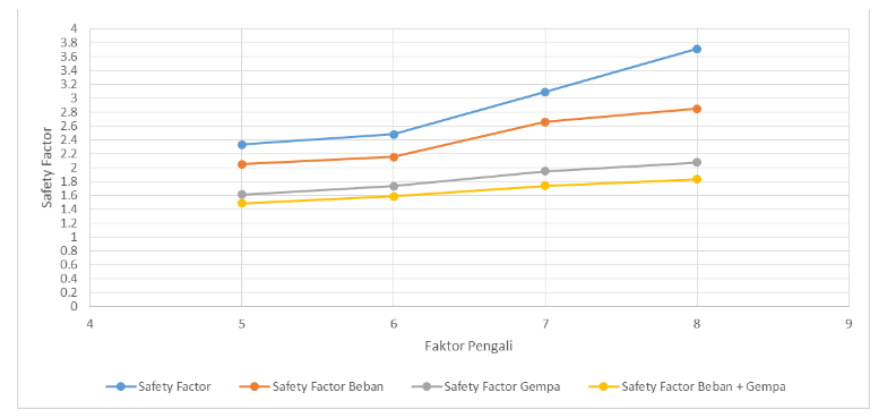

Gambar 6 Angka keamanan dengan perkuatan 5 Geogrid dan Terramesh

\section{KESIMPULAN}

Dari hasil penelitian yang diperoleh, dapat disimpulkan beberapa hal berikut ini:

1. Berdasarkan Tabel 4.35 diketahui bahwa nilai angka keamanan lereng lebih kecil dari nilai angka keamanan syarat sehingga lereng tersebut termasuk dalam kategori lereng tidak stabil.

2. Perkuatan lereng dapat dilakukan dengan 3 alternatif, yaitu geogrid, terramesh, maupun terramesh dan geogrid. Nilai persentase kenaikan kekuatan dengan masing-masing alternatif sesuai dengan persamaan pada subbab 4.6.4.

3. Nilai persentase kenaikan kekuatan masing-masing alternatif sebagian besar lebih besar dari $100 \%$ sehingga dapat disimpulkan bahwa perkuatan dapat dipilih berdasarkan efektivitas dan efisiensi.

4. Desain dinding penahan tanah dengan Terramesh dan geogrid dapat digunakan sebagai konstruksi dinding penahan tanah pada jalan tol di Jakarta.

5. Penggunaan korelasi untuk mendapatkan parameter tanah desain cukup akurat sehingga konstruksinya dapat diterapkan di lokasi proyek.

6. Peningkatan angka faktor keamanan juga dapat dicapai dengan penggunaan geogrid secara efektif.

\section{DAFTAR PUSTAKA}

Arief, Saifudin. 2007. Konsep Dasar Analisis Kestabilan Lereng. www.scribd.com

Brinkgreve, R.B.J.(2007).Manual PROGRAM 2D Versi 8.Delft : PROGRAM b.v.

Bowles, Joseph E. 1996. Analisa dan Desain Pondasi Jilid 1. Edisi Kelima. Jakarta: Penerbit Erlangga. (Diterjemahkan oleh: Pantur Silaban, Ph.D).

Budhu, Muni. 2011. Soil Mechanics and Foundation. (3rd Edition). New Jersey: John Wiley \& Sons, Inc.

Das, Braja M. 1995. Mekanika Tanah (Prinsip - Prinsip Rekayasa Geoteknis) Jilid 2. Jakarta: Penerbit Erlanga. (Diterjemahkan Oleh: Noor Endah dan Indrasurya B. Mochtar)

Kodoatie, Robert J. 2005. Pengantar Manajemen Infrastruktur. Yogyakarta: Pustaka Pelajar.

Kovacs, William D. 1981. An Introduction to Geotechnical Engineering. New Jersey: Prentice Hall.

Murthy V.N.S. 1977. Geotechnical Engineering. New York: Marcell Dekker.

Riggs, C.O. (1983). Reproducible SPT hammer impact force with an automatic free fall SPT hammer system.

Sandjaja, Gregorius. 2015. Diktat Pondasi Tiang II. Jakarta: Universitas Tarumanagara.

Stephenson D. 1979. Rockfill in Hydraulic Engineering. New York: Amsterdam Oxford.

Terzaghi and Peck. 1967. Soil Mechanics in Engineering Practice. 2nd Edition. Wiley.

Terzaghi, Karl dan Ralph B. Peck. 1987. Mekanika Tanah dalam Praktek Rekayasa Jilid 1. Edisi Kedua. Jakarta: Penerbit Erlangga.

Terzaghi, Karl dan Ralph B. Peck. 1991. Mekanika Tanah dalam Praktek Rekayasa Jilid -2. Edisi Kedua. Jakarta: Penerbit Erlangga. 
